\title{
MENADŽMENT U OBRAZOVANJU I ČINIOCI NJEGOVE EFIKASNOSTI
}

\author{
Ima slikara koji promijene sunce u žutu mrlju, \\ ali ima i drugih, koji pomoću svoje umjetnosti \\ i inteligencije, promijene žutu mrlju u sunce.
}

Pablo Picaso

SAŽETAK

Za razliku od determiniranih, pedagoška djelatnost $u$ školi pripada stohastičkim sistemima, u kojima uspješnost upravljanja, planiranja, odlučivanja, rukovođenja, organiziranja, izvršenja odluka $i$ kontrole sprovođenja odluka, kao osnovne funkcije menadžmenta, imaju posebno značenje. U pristupu identifikaciji i klasifikaciji faktora efikasnosti menadžmenta u obrazovanju, ističe se poseban značaj stila rukovođenja $i$ personalnih karakteristika. Stil rukovođenja se manifestira kroz orijentaciju na odnose i orijentaciju na zadatke, kao dvije determinirajuće dimenzije u rukovođenju. Ukrštanjem ove dvije dimenzije mogu se, s obzirom na stil rukovođenja, identificirati četiri osnovna tipa rukovodioca: izolovani, otvoreni, integrator $i$ posvećenik. Brojna istraživanja su pokazala da neke unutrašnje karakteristike rukovodilaca veoma značajno utječu na organizacionu klimu, a među njima naročito: vlast, talenat, iskustvo $i$ znanje. Karakteristike značajne za uspješnost menadžera mogu se razvrstati $u$ tri osnovne grupe: osobine koje se odnose na sposobnost mišljenja, osjećanja i karakteristike ponašanja. Sve je veći broj autora koji naglašavaju značaj sljedeće četiri psihološke crte za uspješnost menadžera: emocionalna stabilnost, ekstrovertnost, snaga mentalne elaboracije $i$ orijentacija na postignuće. Među unutrašnjim karakteristikama posebno se naglašava značaj posjedovanje vještina. Pored poželjnih unutrašnjih osobina, istraživanjem je utvrđen $i$ veliki broj nepoželjnih karakteristika koje štetno utječu na efikasnost menadžmenta.

\footnotetext{
${ }^{1}$ Pedagoški fakultet u Bihaću
} 
Ključne riječi: ekstrovertnost, emocionalna stabilnost, menadžment, organiziranje, orijentacija na postignuće, planiranje sistema, rukovođenje, snaga mentalne elaboracije, stil rukovođenja, upravljanje.

\section{Uvod u problem}

Efikasna organizacija je strogo uređen sistem u kome su svi elementi povezani tako, da odvijanje jednog omogućuje funkcioniranje narednog elementa. Sistem je povezanost dijelova u skladnu cjelinu, tako da se svaki elemenat odvija u skladu s jedinstvenom cjelinom. U svakoj djelatnosti, pa naravno i u pedagoškoj, u kojoj želimo postići optimalne rezultate, ta djelatnost mora biti uređena kao cjelovit i jedinstven sistem rada.

Pedagoška djelatnost u školama pripada tzv. stohastičkom sistemu $u^{2}$ u kome se elementi ponašaju na nivou vjerovatnosti, ${ }^{3}$ za razliku od determiniranih sistema, kod kojih se upravljačkim odlukama može uticati da se sistem prevede iz jednog u drugo novo stanje, da se mogu sa velikom preciznošću utvrđivati rezultati na izlazu sistema, odnosno, planirati odgovarajući efekti. ${ }^{4}$ Povratna informacija ovdje predstavlja upravljačku polugu, kojom se sistem prevodi iz jednog u drugo stanje, iz manje uređenog u više uređeno i organizirano stanje.

$\mathrm{Na}$ temelju osnovnih funkcija i uloga, efikasnost menadžmenta bi se odnosila na uspješnost upravljanja, planiranja, odlučivanja, rukovođenja, organiziranja, izvršenja odluka i kontrole sprovođenja odluka, odnosno efikasnost bi se morala sagledavati u svakome od segmenata ili područja rada, te aktivnosti menadžmenta. Međutim, sve ove funkcije i uloge su u veoma tijesnoj međusobnoj povezanosti, pa većina autora smatra da je odlučujući faktor za ocenu uspešnosti

\footnotetext{
${ }^{2}$ Stohastika je riječ grčkoga porijekla. Označava vještinu pogađanja, a pogađa se ono što se ne može precizno odrediti.

${ }^{3} \mathrm{M}$. Vilotijević, Osnove naučne organizacije rada škole, Centar za usavršavanje rukovodilaca u obrazovanju, Beograd, 1992., str. 19.

${ }^{4}$ M. Vilotijević, Organizacija i rukovođenje školom, Naučna knjiga, Beograd, 1993., str. 52.
} 
menadžmenta stil rukovođenja, ${ }^{5}$ jer on determinira opću klimu u organizaciji, koja opet utječe na motivaciju za rad i rezultate rada saradnika.

$\mathrm{U}$ analizi efikasnosti menadžmenta u obrazovanju može se prilaziti s različitih stanovišta i mogu se izdvojiti brojni faktori koji utječu na tu efikasnost. Upoređujući te brojne pristupe u identifikaciji i klasifikaciji faktora efikasnosti, uočavaju se dvije osnovne grupe bitnih faktora:

1. stil rukovođenja,

2. personalne, unutrašnje karakteristike.

\section{Stil rukovođenja kao činilac efikasnosti menadžmenta}

$\mathrm{Na}$ osnovu rezultata istraživanja Biroa za poslovna istraživanja $u$ državi Ohajo, Centra za pregledna istraživanja Mičigenskog Univerziteta $i$ Univerziteta u Harvardu urađen je Redinov model uspješnosti stilova rukovođenja ${ }^{6} \mathrm{u}$ kojem su praćene dvije determinirajuće dimenzije u rukovođenju:

1. orijentacija na zaposlene ili orijentacija na odnose - Relation Orientation: $R O$,

2. orijentacija na produktivnost ili orijentacija na zadatke - Task Orientation: TO.

Prema ove dvije dimenzije, Redin je konstruirao kvadrat s četiri polja i s koordinatama 0,2 i 4 , gdje se mogu identificirati četiri osnovna tipa rukovodilaca, prema stilu rukovođenja.

Za efikasnost menadžmenta značajno je kojem od četiri navedena stila rukovođenja on pripada, odnosno koja je njegova pozicija u koordinatama na dva kontinuuma ili dvije osnovne orijentacije $u$ rukovođenju. Osnovne karakteristike ovih tipova rukovođenja su:

\footnotetext{
${ }^{5}$ D. Ristić, Osnovi menadžmenta, Fakultet za menadžment, Novi Sad, 2002., str. 169.

${ }^{6}$ Ibid., str. 170 .
} 


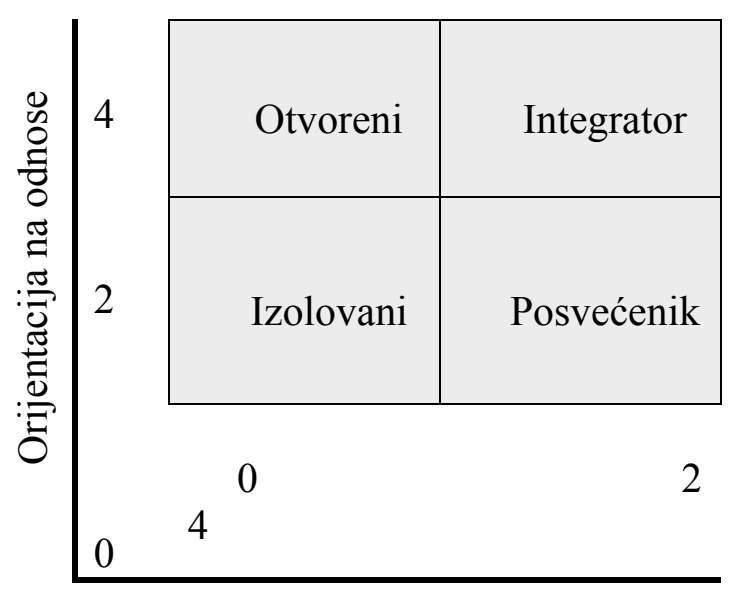

Orijentacija na zadatke

1. Izolovani tip rukovodioca je onaj koji ima niže vrijednosti i na skali orijentiranosti na zadatke i na skali orijentiranosti na odnose. Takvi menadžeri skloni su da ukazuju i stalno ispravljaju greške svojih saradnika, naglašeno preferiraju iskustva iz prošlosti, vole sve zapisivati, puno drže do pravila i propisa, potenciraju parlamentarnost i hijerarhijsko uvažavanje, vole rutinski rad i administriranje, ne smatraju bitnom vještinu upravljanje međuljudskim odnosima, pribjegavaju pooštravanju kontrole i kažnjavanju saradnika, ne ispoljavaju inovativnost, emocionalno su distancirani, rezervirani i oprezni;

2. Otvoreni tip rukovodioca. Menadžeri za koje je karakterističan ovaj stil rukovođenja više su orijentirani na odnose nego na zadatke. Oni najviše vremena posvećuju zaposlenima, fokusirani su na interpersonalne odnose u organizaciji, žele o njima biti informirani, unapređivati ih ali i držati pod stalnom kontrolom (vladati situacijom), oni su socijalno usmjereni tip rukovodioca $;^{7}$

3. Integrator predstavlja stil rukovođenja koji se susreće kod menadžera naglašeno visoko orijentiranih $i$ na odnose $i$ na produktivnost. Menadžeri ovoga tipa forsiraju timski rad, povezuju se i s pojedincima i s grupama, ispoljavaju spremnost za saradnju i s podređenima i s nadređenima; istražuju uzroke konflikata, žele biti

${ }^{7}$ D. Ristić, Osnovi menadžmenta, Fakultet za menadžment, Novi Sad, 2002., str. 171 . 
stalno uključeni u događaje i tokove zbivanja, orijentirani su na ciljeve i na budućnost;

4. Posvećenik označava menadžera koji je u svome stilu rukovođenja maksimalno orijentiran na zadatke, a minimalno na odnose. Ovakav rukovodilac više insistira na zahtjevima procesa $i$ na procedurama, nego što vodi računa o međuljudskim odnosima; ${ }^{8}$ ponaša se $\mathrm{s}$ pozicije nadređenoga, ocjenjuje i naređuje, sklon je kažnjavanju, primjenjuje pritisak u rješavanju konflikata, sumnjičav je i sklon prepirkama i optuživanju.

Navedeni stilovi rukovođenja klasificiraju menadžere prema njihovoj orijentiranosti na odnose $i$ na ciljeve, ali ne utvrđuju efikasnost menadžmenta. Pored ove klasifikacije Redin navodi četiri stila rukovođenja koji karakterišu uspješne i četiri stila koji karakterišu neuspješne menadžere, a koji, zapravo, nastaju iz ovih osnovnih stilova. ${ }^{9}$ Dakle, iz svakog od ova četiri osnovna stila rukovođenja može nastati tip uspješnog ili tip neuspješnog menadžera.

\begin{tabular}{|c||c|l|}
\hline Osnovni stil & $\begin{array}{r}\text { Tip uspješnog } \\
\text { stila rukovođenja }\end{array}$ & $\begin{array}{c}\text { Tip neuspješnog } \\
\text { stila rukovođenja }\end{array}$ \\
\hline \hline Izolovani & Birokrata & Dezerter \\
\hline Otvoreni & Inovator & Misionar \\
\hline Integrator & Izvršilac & Kompromiser \\
\hline Posvećenik & $\begin{array}{c}\text { Blagonakloni } \\
\text { autokrata }\end{array}$ & Autokrata \\
\hline
\end{tabular}

Osnovne karakteristike tipova uspješnog stila rukovođenja, prema D. Ristiću ${ }^{10}$. su slijedeće:

\footnotetext{
${ }^{8}$ Ibid., str. 171.

9 R. Čaušević, Psihološke osnove menadžmenta u obrazovanju, TDP Sarajevo, 2007., str. 67.

${ }^{10}$ Ristić D., o. c., str. 174.
} 
a) Birokrata - uvažava propise, pravila i procedure, čvrst, pouzdan u stavovima i postupcima, brine se o svim dijelovima organizacije i brine za nju, drži do svih detalja, racionalan, odmjeren, precizan;

b) Inovator - socijalno usmjeren, ostvaruje široke kanale komuniciranja, zna slušati, podstiče i razvija talenat drugih, razumije druge i pomaže im, dobro sarađuje, uživa povjerenje drugih;

c) Izvršilac - kooperativan u radu, primjenjuje timski rad u odlučivanju, zna motivirati, ubijediti i povesti ljude da se sami obavežu za ostvarivanje ciljeva firme, podstiče ljude na efikasnost, uspješno usklađuje rad svojih saradnika;

d) Blagonakloni autokrata - odlučan, ima inicijativu, veoma radan i energičan, odluke i zamisli zna sprovesti do kraja, odgovoran prema obavezama, vodi računa o troškovima, orijentiran je na dobit $i$ ostvaruje dobre rezultate u radu.

Neuspješni stilovi rukovođenja, koji proizlaze iz osnovnih stilova, imaju sljedeće osnovne karakteristike:

a) Dezerter - izbjegava obaveze, odgovornosti i saradnju, nekreativan je i ne daje često korisne sugestije i prijedloge za rad, uskogrudan je, ometa druge u njihovoj kreativnosti, zadovoljava se krutim pridržavanjem propisa;

b) Misionar - socijalno umjeren ali neuspješan, ljubazan je, srdačan i prijatan u komuniciranju, izbjegava konflikte, želi se dopasti drugima i na štetu posla, pasivan je, uproštava stvari, izbjegava inicijativu;

c) Kompromiser - sklon zloupotrebi saradnje, nepostojan $\mathrm{u}$ odnosima sa saradnicima, izbjegava odlučivanje, a kad donosi odluke, one su neodređene, kompromisne i bez mogućnosti efikasne primjene, iako naglašava spremnost za pravilne odnose i saradnju, ne uspijeva to provesti;

d) Autokrata - kritičan je, voli pratiti koristeći metode prisile, o svemu odlučuje sam, traži pokornost i poslušnost, guši konflikte ne nastojeći otkloniti njihove uzroke, od svake akcije očekuje rezultate, komunicira samo jednosmjerno. 
Naravno, da se tipologija i klasifikacija efikasnosti menadžmenta nipošto ne može $\mathrm{i}$ ne smije kruto $\mathrm{i}$ bukvalno shvatati: zavisno od ličnosti samog menadžera, od stila rada i osobina njegovih saradnika i od same konkretne situacije, jedna ista osobina stila rukovođenja može imati dijametralno različitu efikasnost ${ }^{11}$. Ostvarivanje postavljenih ciljeva organizacije je glavno mjerilo uspješnosti menadžmenta, jer uspešnost rukovodioca se ne meri po tome kako radi, nego po rezultatima koje postiže. ${ }^{12}$

\section{Personalne karakteristike kao činilac efikasnosti menadžmenta}

Brojna istraživanja su pokazala da neke unutrašnje karakteristike rukovodilaca veoma značajno utječu na organizacionu klimu, a među njima naročito: vlast, talenat, iskustvo i znanje. ${ }^{13} \mathrm{Na}$ uspješnost menadžmenta u nekoj organizaciji, pored brojnih faktora koji se odnose na aktivnosti menadžera u sklopu njegovih funkcija i uloga a koje uvjetno možemo označiti kao eksterne, utječe i velik broj unutrašnjih činilaca koji se odnose na unutrašnje, individualne karakteristike samoga menadžera, kao osobe ili individue.

Neophodno je imati u vidu da su svi ovi činioci međusobno veoma tijesno i kompleksno povezani i da, osim što djeluju zajedno na efikasnost menadžmenta, oni i međusobno djeluju jedni na druge. Tako npr., znanje ili iskustvo, kao unutrašnja karakteristika menadžera, utječe direktno na njegovu efikasnost u obavljanju funkcije, ali i indirektno, jer od ovih karakteristika može ovisiti i njegov stil rukovođenja ili njegova orijentiranost, način komuniciranja, način ostvarivanja kontrole itd.

Ako se prati svaka od ovih pojedinih karakteristika u pojedinim oblicima organizacione klime, može se uočiti i zaključiti sljedeće:

1. Vlast, kao karakteristika menadžera, ima najveći stepen korištenja u autoritarnoj i kvazidemokratskoj klimi, dok je u odnosu na ostale unutrašnje karakteristike, najmanje prisutna u kooperativnoj i demokratskoj klimi u organizaciji. Kao izvorište moći i utjecaja vlast ima velik značaj i u klimi lese-fer tipa, a u

\footnotetext{
${ }^{11}$ R. Čaušević, o. c., str. 67.

${ }^{12}$ D. Ristić, o. c., str. 174.

${ }^{13}$ D. Ristić, ibid.
} 
birokratskoj klimi njen utjecaj iako niži od znanja i iskustva, ipak se stabilizira;

2. Talenat se javlja kao najznačajniji od četiri navedena faktora jedino $\mathrm{u}$ organizacijama $\mathrm{s}$ birokratskom organizacionom klimom. Na kontinuumu od autoritarne do demokratske klime, utjecaj ove lične karakteristike menadžera opada;

3. Iskustvo kao lična karakteristika menadžera najniži stepen korištenja ima u organizaciji sa autoritarnom klimom, a idući dalje prema demokratskoj klimi utjecaj ovoga faktora blago raste. Međutim, ni u jednome slučaju osim djelomično u kooperativnoj klimi, ovaj faktor nema dominantan značaj;

4. Znanje se, kao lična karakteristika menadžera, najmanje koristi $\mathrm{u}$ autoritarnoj organizacionoj klimi, dok njegov utjecaj, idući dalje prema demokratskoj klimi, progresivno raste.

Ako se komparativno analizira povezanost personalnih karakteristika menadžera i organizacione klime, može se zaključiti da će u nekoj organizaciji dominirati autoritarni stil rukovođenja ako menadžer koristi dominantno vlast, a minimalan značaj daje znanju; dok će u obrnutome slučaju, kada menadžer u svome stilu rukovođenja apsolutnu prednost daje znanju, zatim iskustvu, pa talentu, a ne nastupa dominantno sa pozicije vlasti, organizaciona klima biti demokratska. ${ }^{14}$

Brojna istraživanja su potvrdila utjecaj karakteristika ili svojstava menadžera na efikasnost obavljanja njegove funkcije i u literaturi se susreću liste tih karakteristika od različitih autora. Džon Ader (John Adair) daje svoju listu od 12 sljedećih faktora koji utiču na efikasnost menadžmenta: odlučnost, liderstvo, integritet ličnosti, entuzijazam, imaginacija, spremnost da se radi mnogo, sposobnost analitičnosti, razumijevanje drugih, sposobnost uočavanja šansi, sposobnost suočavanja s neprijatnim situacijama, sposobnost brze adaptacije na promjene i spremnost preuzimanja rizika. ${ }^{15}$

Lista ovih karakteristika se ne treba i ne može shvatiti kao gotov recept ili model uspješnoga menadžmenta, niti redoslijed navedenih

\footnotetext{
${ }^{14}$ R. Čaušević, o. c., str. 69.

${ }^{15}$ D. Ristić, o. c., str. 176 - 178.
} 
karakteristika određuje njihov rang po značaju. U poslu menadžera, kao i pri obavljanju svake druge profesije, potreban je visok stepen prilagodljivosti situaciji, njenim specifičnostima i zahtjevima, jer bilo koje od ovih svojstava ne mora biti generalno efikasno u svim situacijama $^{16}$.

Listu karakteristika koje su značajne za uspješnost menadžera, prema Bolvelu, čini sljedećih 10 karakteristika: inteligencija, sposobnost saradnje $s$ drugima, iskustvo u području tehničke kompetencije, sposobnost motiviranja sebe $i$ drugih, emocionalna stabilnost $i$ samokontrola, iskustvo $i$ vještina planiranja $i$ organiziranja, snažna želja za ostvarenjem zadataka, sposobnost korištenja grupnih procesa, sposobnost da se bude efikasan $i$ uspješan, te odlučnost. ${ }^{17}$

Aderova i Bolvelova lista imaju određene sličnosti, mada se razlikuju u načinu formulisanja pojedinih karakteristika.

Heri Levinson (Harry Levinson) navodi 20 karakteristika značajnih za uspješnost menadžera, koje su svrstane u tri osnovne grupe:

1. Osobine koje se odnose na sposobnost mišljenja (sposobnost apstrakcije, tolerantnost $u$ neizvjesnosti, inteligencija $i$ sposobnost prosuđivanja);

2. Osjećanja i unutrašnje osobine (autoritet, aktivnost, ostvarivost, senzitivnost, angažiranost, zrelost, uvažavanje potreba drugih, stvaranje dobrog utiska, izdržljivost, prilagodljivost i osjećaj za humor);

3. Karakteristike ponašanja (posjedovanje jasne vizije o toku sopstvenog života, karijere $i$ napretka organizacije, sposobnost privrženosti zadacima, posjedovanje dobrog osjećaja za pravovremenost, posjedovanje konzistentnog sistema vrijednosti i socijalna odgovornost). ${ }^{18}$

Personalna ili lična svojstva i obilježja su veoma značajan faktor efikasnosti u obavljanju menadžerske funkcije i zadataka. Različiti

\footnotetext{
${ }^{16}$ R. Čaušević, o. c., str. 70.

${ }^{17}$ Ristić D., o. c., str. 179.

${ }^{18}$ Ibid., str. 181-182.
} 
autori, u skladu sa svojom temeljnom psihološkom orijentacijom, navode različite psihološke karakteristike osobnosti, kao relevantna unutrašnja obilježja ili personalna svojstva značajna za efikasnost u obavljanju menadžerske funkcije. Prema R. Dunđeroviću ${ }^{19}$ sve je veći broj autora koji naglašavaju značaj sljedeće četiri psihološke crte za uspješnost menadžera:

a) Emocionalna stabilnost. Ova psihološka crta se odnosi na realno sagledavanje sebe, drugih ljudi i situacije, mogućnosti kontrole vlastitih postupaka, povjerenja u sebe i vjerovanja u vlastiti uspjeh, nepostojanje konflikta između vlastitih želja i mogućnosti. Emocionalna stabilnost je sastavna komponenta emocionalne zrelosti i bitan činilac efikasnosti menadžera, jer uspješan menadžer mora imati visok stepen svjesne emocionalne samokontrole;

b) Ekstrovertnost. Označava svojstvo ličnosti koje se manifestira kroz otvorenost, komunikativnost, preduzimljivost, lahko uključenje u grupu i sklapanje prijateljstva, općenito, usmjerenost prema drugima za razliku od introvertnosti koja označava usmjerenost i okrenutost pojedinca prema sebi. Ekstrovertna orijentacija pomaže menadžeru da uspješnije uoči razlike u ponašanju svojih saradnika, da se realnije postavi prema onima koji su sa manjim samopouzdanjem, koji su impulsivni, preosjetljivi, da uspostavi neposredniju komunikaciju sa ljudima $i$ da ostvari jaču kontrolu vlastitoga ponašanja i funkcioniranja;

c) Snaga mentalne elaboracije. Pod ovom psihološkom crtom se podrazumijeva moć pojedinca menadžera da shvati $i$ vrednuje svoje mogućnosti $i$ htenja s jedne strane, $i$ ukupnost zahteva koje pred njega postavlja njegova prirodna i socijalna sredina, $s$ druge strane. ${ }^{20}$ Osobe s većom snagom mentalne elaboracije imaju realniju i jasniju sliku o sebi, veće samopouzdanje, realan odnos prema stvarnosti koja ga okružuje, spremnije su da se prihvate teških zadataka, ispoljavaju više sistematičnosti i odgovornosti, teže ih je pokolebati, a time su im i veće šanse za uspješnije obavljanje menadžerske funkcije;

\footnotetext{
${ }^{19}$ R. Dunđerović, Osnovi psihologije menadžmenta, Fakultet za menadžment, Novi Sad, 2005., str. 92.

${ }^{20}$ R. Dunđerović, o. c., str. 94.
} 
d) Orijentacija na postignuće. Posebna je crta ličnosti koja se manifestira kroz težnju pojedinca da postigne uspjeh u nekoj djelatnosti. Osobe koje nisu orijentirane na postignuće, imaju nizak nivo aspiracije, zadovoljavaju se minimalnim rezultatima, ili čak ne postavljaju sebi nikakve ciljeve koje žele postićí ${ }^{21}$.

U psihološkoj literaturi se sve češće susreću pristupi po kojima se psihološke osobine značajne za uspješnost menadžera grupišu u određeni broj širih grupa i tretiraju se kao vještine. I. Štajnberger i S. Čizmić pod tim pojmom podrazumijevaju sve što je organizovano, učenjem stečeno, što je dovelo do usklađenih mentalnih $i$ fizičkih aktivnosti ${ }^{22}$ a što utječe na efikasnost obavljanja funkcije menadžera. Ove vještine se mogu svrstati u pet osnovnih grupa ${ }^{23}$ :

a) Tehničke vještine. U svojim redovnim aktivnostima koje se odnose na planiranje, istraživanje, informiranje i sl., menadžer je upućen na korištenje brojnih dostignuća tehničke i informatičke tehnologije. Uspješan menadžer danas mora biti tehnički, tehnološki i informatički osposobljen; on mora ovladati vještinama korištenja dostignuća u tim oblastima;

b) Interpersonalne vještine. Ove vještine se zasnivaju na sposobnostima menadžera u rukovođenju kadrovima, motiviranju zaposlenih, upravljanju konfliktima među ljudima i uopće, u radu s drugim ljudima. Osnovu za ovladavanje personalnim vještinama čini socijalna inteligencija i sposobnost shvatanja $i$ razumevanja odnosa među ljudima, ${ }^{24}$ a bitan značaj imaju i brojne karakteristike ličnosti menadžera koje mu pomažu u boljem snalaženju u međuljudskim odnosima;

c) Konceptualne vještine menadžera. Obuhvataju sposobnosti sagledavanja, shvatanja, prepoznavanja i detektiranja svih činilaca koji djeluju u odnosima organizacije i njenoga šireg okruženja. Ove vještine su značajne za realnu percepciju organizacije i sagledavanje njene pozicije, kao i za uspješno obavljanje menadžerskih funkcija

\footnotetext{
${ }^{21}$ R. Čaušević, o. c., str. 72.

${ }^{22}$ S. Čizmić, et all., Psihologija i menadžment, Filozofski fakultet, Beograd, 1995., str. 31.

${ }^{23}$ R. Čaušević, o. c., str. 73.

${ }^{24}$ S. Čizmić, et all., o. c., str. 32.
} 
organiziranja, pregovaranja, rješavanja nemira i konflikata $u$ organizaciji i sl;

d) Komunikacione vještine. Uključuju sposobnosti, stavove i osjećanja menadžera $u$ procesu slanja $i$ primanja informacija. Komunikacija u kojoj učestvuje menadžer je stalan proces; on ostvaruje kontakte sa svojim saradnicima, radnicima, okruženjem, i bez obzira da li je ta komunikacija u pisanoj ili usmenoj formi, da li je verbalna ili neverbalna, ona značajno utječe na ukupnu efikasnost menadžmenta organizacije;

e) Vještina kreativnog rješavanja problema. Uspješan menadžer mora biti vješt u uočavanju, prepoznavanju i fokusiranju problema i u njihovom praktičnom rješavanju. Prema A. Raič, rješavanje problema je proces racionalne analize, koji prolazi kroz sedam etapa: ${ }^{25}$

- shvatanje problema i njegovo jasno postavljanje,

- prikupljanje podataka i informacija,

- utvrđivanje mogućih uzroka,

- razrada mogućih rješenja,

- procjena i vrednovanje različitih rješenja,

- izbor najpovoljnijeg rješenja i donošenje odluke,

- sprovođenje odluke i praćenje njenih rezultata.

Svaka od navedenih grupa vještina značajna je i neophodna za uspješnost menadžera u obavljanju njegovih funkcija i uloga, ali se ipak neke od ovih vještina posebno preferiraju. Po mišljenju nekih autora $^{26}$ za top-menadžera je ključno posjedovanje konceptualnih vještina i vještina kreativnoga rješavanja problema, za menadžere srednje linije interpersonalne i komunikacijske vještine, a za menadžere-supervizore, tehničke vještine.

Kroz intervjue s direktorima i zaposlenima Lester R. Bittel je došao do sljedećih jedanaest poželjnih svojstava vođe: ${ }^{27}$

${ }^{25}$ A. Raič, Sportski menadžment, Sportska akademija, Beograd, 1999., str. 77-78.

${ }^{26}$ S. Čizmić, et all., o. c., str. 34.

27 R. L. Bittel, Osobine sposobnih vođa, Časopis Direktor škole, br. 2/2001., Beograd, 2001., str. 6. 
1. Energija. Uspješne vođe odlikuje stalna pokretljivost, upornost, energičnost. Unutrašnja pokretačka snaga omogućuje menadžerima da prebrode prepreke i da budu istrajni tamo gdje bi se drugi pokolebali ili bi promijenili svoje mišljenje;

2. Istrajnost. Ovo je svojstvo u direktnoj vezi sa energetskim kapacitetom svakoga pojedinca. Mnoge poslovne situacije traže upornost i ustrajnost i uspješan menadžer ih mora posjedovati i računati na njih;

3. Obrazovanost. Formalno obrazovanje svakako doprinosi uspješnome liderstvu, ali ne predstavlja njegov neophodni sastavni dio. Menadžeri trebaju permanentno sticati znanja iz svih raspoloživih izvora, ne propuštati nijednu mogućnost da svoj fond informacija obogate novim, koje su u vezi s njihovom profesijom. Osoba koja posjeduje znanje djeluje većom snagom na druge i njeni saradnici od nje dobivaju uputstva i usmjeravanja u poslu;

4. Inteligencija. Dometi u obrazovanju ponekad predstavljaju dokaz inteligencije, ali to predstavljaju i ostvarenja na poslu. Inteligentan menadžer zapaža šta se događa oko njega i u stanju je brzo reagirati;

5. Zdravo rasuđivanje. Sposobnost zaključivanja i rasuđivanja je bitna za ispravno donošenje odluka, ali i za opći dojam drugih u organizaciji o svom menadžmentu. Povjerenje u odluke menadžmenta je veće ako se pokazalo da je menadžer uvijek donosio ispravne odluke;

6. Izgled. U konkurenciji za ulogu vođe često je značajna prednost fizički izgled osobe, njena atletska građa, stas, visina i druge karakteristike općeg izgleda i držanja. Pokazalo se da fizički potentne osobe i osobe prijatnoga fizičkog izgleda lakše zadobivaju tuđe povjerenje;

7. Ličnost. U ovome kontekstu pod ovim svojstvom se podrazumijeva uglavnom svojstvo ličnosti koje se manifestira kroz nadmoć, izvjesnu superiornost i sposobnost upravljanja drugima, što kod drugih stvara dojam moći, uspješnosti i sposobnosti pronalaženja pravih rješenja u teškoćama i problemima; 
8. Samopouzdanje. Uspješan menadžer ne smije biti opterećen stalnim strahom kako neće uspjeti ili da će napraviti neku grešku, te da će ga zamijeniti neko od onih koji su mu sad potčinjeni. Istinsko samopouzdanje je uvjerenje zasnovano na znanju, gledanju u budućnost i dokazanom uspješnom radu;

9. Kreativnost $i$ inicijativa. Uspješan menadžer uvijek mora biti ispred drugih i mora se osloboditi zavisnosti od grupe. Najbolje ideje za poslove i nove strategije u ostvarenju postavljenih ciljeva organizacije, moraju dolaziti prvo od njega. Međutim, to ne znači da on neće saslušati i pokazati interes i za ideje svojih saradnika, ali te ideje mora razmotriti i izvršiti kvalitetan izbor;

10. Objektivnost $i$ uravnoteženost. U periodima uspona i uspjeha kod menadžera se može javiti pretjerano visoko mišljenje o samome sebi, a isto tako u periodima teškoća, kriza i konflikata u organizaciji gubitak samopouzdanja, osjećaj bezvrijednosti, nemoći i inferiornosti. Uspješan menadžer mora biti uravnotežena osoba koja će imati objektivno mišljenje o sebi, svojim mogućnostima i kapacitetima u svim prilikama;

11. Oduševljenje i optimizam. Ove osobine su vanjski pokazatelji samopouzdanja i ako ih menadžer iskreno ispoljava, radnici imaju veći stepen povjerenja u njega. ${ }^{28}$

Ichak Adizes, analizirajući odnos uzajamnoga povjerenja, poštovanja i svojstava ljudi, navodi kako dobro uravnoteženi samoaktuelizirani ljudi imaju sljedeće karakteristike, koje ih čine poželjnim ljudima i koje su značajne za efikasnost menadžera:

- Imaju dobro zaokružen i fleksibilan stil rukovođenja;

- Poznaju sami sebe;

- Svjesni su svoga uticaja na druge ljude;

- Imaju uravnotežen pogled na same sebe;

- Svjesni su sopstvenih slabosti;

- Znaju prepoznati vrline drugih;

- Prihvataju druge koji se od njih razlikuju;

${ }^{28}$ R. Čaušević, o. c., str. 78. 
- U stanju su se suočiti s konfliktom i iskoristiti ga;

- Stvaraju sredinu u kojoj se uči. ${ }^{29}$

Prema A. Raič postoji deset antiosobina uspješnoga liderstva, odnosno sljedećih deset osobina uspješan menadžer ne bi trebao posjedovati:

- neosjetljivost za druge, zajedljivost, familijarnost,

- hladnoća, uzdržanost, drskost i nadmenost,

- izneveravanje date reči i poverenja,

- preterana ambicija, igranje politike,

- preterano nadziranje, odsustvo delegiranja (prenošenja) ovlašćenja na potčinjene,

- nesposobnost stvaranja jednodušnog (kohezivnog) tima,

- biranje slabih i neuspešnih potčinjenih,

- otežano strategijsko mišljenje,

- neelastičnost prilagođavanja različitim šefovima,

- preterana zavisnost prema mentoru (savetniku). ${ }^{30}$

Bez obzira što se navedene osobine ne odnose isključivo na menadžment u obrazovanju, već na menadžment uopće, veoma je bitno da menadžer, odnosno direktor škole, ima u vidu i vodi računa o osobinama koje bi on trebao posjedovati kao preduvjet efikasnog ostvarenja svoje menadžerske funkcije i uloge u školi. Svaka od ovih osobina istovremeno je direktno vezana i primjenjiva i na sferu menadžmenta u obrazovanju ${ }^{31}$.

Kada se radi konkretno o obrazovanju, odnosno menadžmentu u obrazovanju, M. Vilotijević izdvaja sljedeće tipove efikasnog direktora-organizatora: ${ }^{32}$

29 I. Adizes, Uzajamno poverenje, poštovanje i svojstva ljudi, Časopis Direktor škole, br. 4/95., Beograd, 1995., str. 52.

${ }^{30}$ A. Raič, o. c., str. 73.

${ }^{31}$ R. Čaušević, o. c., str. 79.

${ }^{32}$ M. Vilotijević, Programiranje rada direktora škole, Časopis Direktor škole, br. 2/96., Beograd, 1995., str. 27. 
1. Odlučivač. Ovaj tip direktora karakteriše donošenje vrijednih i dobrih odluka, gdje se koristi timski pristup, poticanje i ohrabrenje saradnika. Direktori ovoga tipa nastoje svojim podređenima što bolje i preciznije predočiti ciljeve i zadatke, te ih pridobiti na saradnju;

2. Slušatelj-komunikator. Direktori ovoga tipa dobro poznaju svoje saradnike, njihove interese, potrebe i težnje. Oni strpljivo saslušaju svoje saradnike kao sagovornike, nisu nametljivi, nisu oni koji dominiraju sastankom i dopuštaju da i drugi iznesu svoje stavove i svoje mišljenje;

3. Učitelj. Ovaj tip direktora svoje podređene, saradnike i buduće menadžere upućuje i podučava kako bolje i efikasnije da rade $\mathrm{i}$ da budu uspješni. Oni vjeruju drugima, daju im uputstva, delegiraju pravično određene zadatke, zahtjeve i ovlaštenja;

4. Mirotvor. Karakteristika ovoga tipa direktora-organizatora ogleda se u tome da na vrijeme mogu uspješno identificirati potencijalna žarišta koja mogu izazvati konflikte i u njihovoj sposobnosti je umijeće reduciranja, smanjenja i otklonuća konfliktnih situacija;

5. Vizionar. Ciljeve, kao idealne slike željene budućnosti, direktori-organizatori ovoga tipa postavljaju onoliko često koliko su ovi ciljevi osmišljeni. Oni postavljau jasne, konkretne, realne, razumljive i dostižne ciljeve;

6. Samokritičar. Efikasni menadžeri ovoga tipa otvoreni su prema sugestijama svojih podređenih i saradnika, te su spremni svoje greške priznati $i$ ispraviti ih. Greške nisu dio njihove prakse $u$ organizaciji i rukovođenju, oni nisu osvetoljubivi prema onima koji ih kritikuju ili osuđuju; oni kao šefovi ne traže uvijek biti u pravu, nego samo onda kada to stvarno jesu;

7. Kapiten tima. Ovaj tip efikasnoga direktora-organizatora zasniva i praktikuje donošenje odluka uz postizanje opće i pune saglasnosti, čime doprinosi otklanjanju nezadovoljstva i podizanju motivacije kod realizatora i izvršilaca odluka, u čijem su donošenju i sami učestvovali; 
8. Direktor-vođa. Direktor ovoga tipa u vođenju kolektiva svoj odnos zasniva na povjerenju i osjetljivosti za lične probleme svojih radnika. On je strpljiv, ne manipulira pojedincima, već ih istinski vodi i usmjerava.

U unutrašnje karakteristike menadžera koje su značajne za njegovu uspješnost mnogi autori, pored karakteristika vezanih za ličnost menadžera, način njegovog ponašanja i funkcioniranja, ističu i značaj temperamenta i karaktera menadžera, naglašavajući time da je emocionalna priroda ličnosti i njeno ponašanje sa stanovišta morala $i$ socijalnih normi, važan činilac efikasnosti obavljanja njenih aktivnosti.

\section{Zaključak}

Funkcija menadžmenta obrazovanja u savremenoj teoriji i praksi dobiva sve više na značenju s obzirom na značaj odgoja i obrazovanja u društvu i njegovom razvoju, specifičnostima ove oblasti kao stohastičkoga sistema i kompleksnosti upravljanja ljudskim resursima u ovome procesu. Efikasnost menadžmenta u obrazovanju može se analizirati s različitih stanovišta i pristupa, pri čemu se mogu izdvojiti brojni faktori koji utječu na tu efikasnost. Upoređujući te brojne pristupe u identifikaciji i klasifikaciji faktora efikasnosti, mogu se izdvojiti dvije osnovne grupe bitnih faktora: stil rukovođenja i personalne, unutrašnje karakteristike. Na osnovu dvije determinirajuće dimenzije stila rukovođenja, koje su određene kao orijentacija na zaposlene i orijentacija na produktivnost, mogu se izdvojiti četiri osnovna tipa rukovođenja: izolovani, otvoreni, integrator i posvećenik. Među personalnim unutrašnjim karakteristikama značajnim za uspješnost menadžera, mogu se izdvojiti tri osnovne grupe: osobine koje se odnose na sposobnost mišljenja, osjećanja i karakteristike ponašanja.

\section{Literatura:}

1. Adizes I., Uzajamno poverenje, poštovanje i svojstva ljudi, Časopis „Direktor škole“", br. 4/95., Beograd, 1995.

2. Bittel R. L., Osobine sposobnih vođa ,Časopis „Direktor škole“ br. 2/2001., Beograd, 2001. 
3. Čaušević, R., Psihološke osnove menadžmenta u obrazovanju, TDP Sarajevo, 2007.

4. Čizmić S., et all., Psihologija i menadžment, Filozofski fakultet, Beograd, 1995.

5. Dunđerović R., Osnovi psihologije menadžmenta, Fakultet za menadžment, Novi Sad, 2005.

6. Raič A., Sportski menadžment, Sportska akademija, Beograd, 1999.

7. Ristić D., Osnovi menadžmenta, Fakultet za menadžment, Novi Sad, 2002.

8. Vilotijević M., Organizacija i rukovođenje školom, Naučna knjiga, Beograd, 1993.

9. Vilotijević M., Osnove naučne organizacije rada škole, Centar za usavršavanje rukovodilaca u obrazovanju, Beograd, 1992.

10. Vilotijević M., Programiranje rada direktora škole, Časopis „Direktor škole“, br. 2/96., Beograd, 1995. 
PROF. DR. FEHIM ROŠIĆ

\section{EDUCATIONAL MANAGEMENT AND ITS EFFICIENCY FACTORS}

\section{SUMMARY}

"There are painters who can change the Sun into a yellow stain, but there are others who can change the yellow stain into a Sun with the help of their art and intelligence." Pablo Picasso

Unlike determined activities, educational activity in school belongs to stochastic systems, in which success of basic management functions such as: performance management, planning, decision making, leadership, organizing, execution of decisions and control of decision implementation has a special meaning. In approach to identification and classification of educational management efficiency factors, a special significance of management style and personal characteristics is emphasised. Management style is manifested through relationship orientation and task orientation, as two determining management dimensions. By mixing of these two dimensions, four basic types of managers can be identified based upon their management style: isolated, open, integrator and devotee. Numerous researches have shown that certain inner manager characteristics significantly influence organizational climate, and among them are: authority, talent, experience and knowledge. Characteristics significant for manager's success can be divided into three basic groups: characteristics related to the thinking ability, emotional ability and behaviour characteristics. Increasing number of authors emphasize importance of following four psychological traits for management success: emotional stability, extroversion, power of mental elaboration and achievement orientation. Importance of skill possession is specially emphasized among the inner characteristics. Apart from desirable inner qualities, research has also detected a large number of undesirable characteristics which adversely affect management efficiency

Key words: management, performance management, system, planning, leadership, management style, emotional stability, extraversion, power of mental elaboration, achievement orientation 
الأستاذ الدكتور فهيم روشيتش

\section{الإدارة التعليمية وعوامل فعاليتها}

\section{خلاصة البحث}

"هناك من الرسامين من يغيّر الشمس إلى بقعة صفراء، ولكن هناك آخرون يغيّرون البقعة الصفراء إلى شمس مستخدمين فنهم وذكاءهم." بابلو بيكاسو

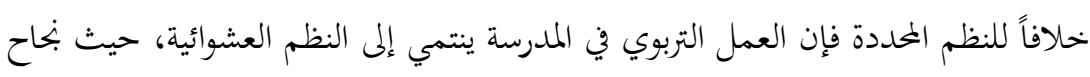
الإدارة والتخطيط واتخاذ القرار والقيادة والتنظيم والتنفيذ والمراقبة لتنفيذ القرار، كالوظيفة الأساسية للإدارة، له معنى خاص. لإده والتخطيط عند معالجة تحديد وتصنيف العوامل المؤثرة في فعالية إدارة التعليم تبرز أهمية خاصة لأسلوب القيادة والصفات الشخصية. يتجلى أسلوب القيادة من خلال التوجه للعلاقات والمهام،

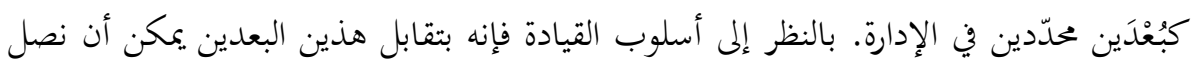

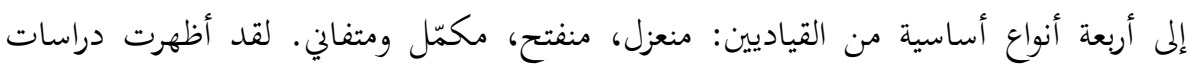

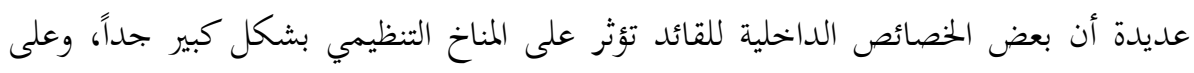

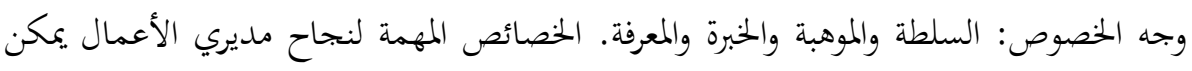

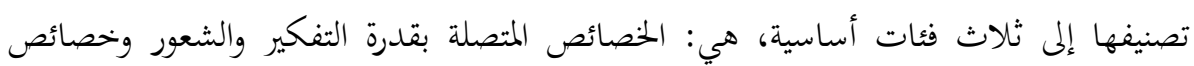
السلوك.

يزداد عدد المؤلفين الذين يؤكدون على أهمية السمات النفسية الأربعة التالية لنجاح مديري الأعمال: الاستقرار العاطفي، جذب الانتباه، وقوة العرض العقلية والتوجه للنجاح. من بين لئن

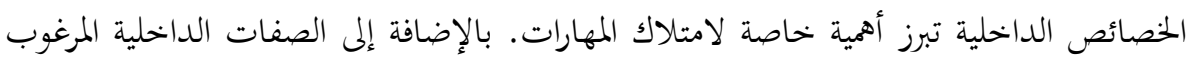
فيها، لقد أثبتت البحوث عدداً كبيراً من الصفات غير المرغوب فيها التي تؤثر سلباً على فعالية الإدارة.

الكلمات الرئيسة: الإدارة، النظام، التوجيه، التخطيط، التنظم، القيادة، أسلوب القيادة، الاستقرار العاطفي، جذب الانتباه، قوة العرض العقلية، التوجه للنجاح. 